\title{
An Evaluation of E-Learning and User Satisfaction
}

\author{
Vijay Anand Rajasekaran, Vellore Institute of Technology, India \\ Kumar K. R., Adhiyamaan College of Engineering (Autonomous), India \\ Susi S., Shadan Women's College of Engineering and Technology, India \\ Mohan Y. C., Bapuji Institute of Engineering and Technology, India \\ Muntha Raju, Shadan College of Engineering and Technology, India \\ Mohammed Waheeduddin Hssain, Shadan College of Engineering and Technology, India
}

\begin{abstract}
The qualification between learning substance and site content should be parallel whereby both will impact one another and influence user satisfaction and fulfillment. After the examination has closed, concern emerges on how the elements of e-learning in service, system, and information quality influence the nature of the e-learning framework in keeping fit. Realizing that client is a mainstay of e-learning framework, this exploration expected to see if the user fulfillment has any impact on e-learning framework quality. Framework plan, framework conveyance, and framework result have been utilized as a stage for estimating the accomplishment of the e-learning framework.
\end{abstract}

\section{KEYWORDS}

E-Learning, Information Quality, Service Quality, System Quality

\section{INTRODUCTION}

As the quick change in education setting proceeds with, associations are compelled to swing to learning association or canny association so as to upgrade their aggressiveness. Customary preparing can never again coordinate the speed of association advancement; consequently, innovation has apparent ramifications for authoritative ability and representative improvement to address these difficulties. Various reviews and research has demonstrated that India today needs monstrous skilling in the event that needs to harvest the statistic profit of having over a large portion of the populace younger than 25 . Be it in schools or universities or in work instruction space, there is a serious lack of talented educators, teachers and coaches. Likewise the associations of today need to re-design and re-situate themselves like clockwork, if not months, to keep themselves in front of the opposition. This again requires serious preparing and re-preparing. The best way to fill the hole in learning in essential/advanced education, professional instruction and abilities preparing in associations is to grasp E-Learning. The time is ready presently to receive E-Learning since exponential development in correspondence innovation has brought about abnormal state of dissemination of web at a lower cost. Additionally clients can get to the taking in substance from anyplace through different gadgets like tablets, cell phones and 
so forth separated from PCs. MOOCs add another measurement to e-learning. In such a situation, we can expect a huge upsurge in e-learning in India in the quick future.

Alex Bennet and David Bennet (2008) the job of feeling in adapting explicitly, e-learning and its relationship to the marvel called enthusiastic learning. With innovation comes a characteristic energy as far as availability and its help of self-driven, experiential realizing, which is a piece of the transformative legacy. As the comprehension of the neuroscience and science of human learning propels, the individual needs of individual students are being started to see well. Uniting these requirements with e-learning framework abilities will offer a noteworthy bounce in the learning rate and productivity as we move into a future loaded up with change, vulnerability, unpredictability and anxiety. Bob Little (2001) under strain from present day business conditions and practices, innovation is being outfit to enable more individuals to take in more things speedier than any other time in recent memory along these lines empowering them not exclusively to accomplish more things however to do new things, and show improvement over would have been the situation under the customary, instructor led preparing framework. There is a threat, in any case, that individuals will begin to look all starry eyed at "innovation" and disregard the benefit of guaranteeing that e-learning materials provide food for students' needs and pursue the standards of compelling instructional structure. One of the main organizations in the field of delivering custom fabricated e-learning arrangements, VEGA Skill change, plots the two its logic and the procedure it uses to guarantee this is the situation. Cheul Rhee et al, (2006) the exploration is to inspect the impacts of interface consistency on the learning execution of gifted and amateur PC clients who are considering with web-based e-learning frameworks. Talented understudies made a larger number of blunders than amateurs when utilizing a physically conflicting e-learning framework. The learning fulfillment dimension of those talented with PCs was lower than that of tenderfoots utilizing such a framework. Thoughtfully predictable frameworks encouraged talented understudies' learning fulfillment. Communicational predictable frameworks shut the accomplishment hole inside the tenderfoot understudy gathering. Be that as it may, the impact of communicational consistency on talented understudies was conflicting. Christina Mainka and Angela Benzies, (2006) e-learning offers many energizing open doors for supporting a wide scope of understudies to take in more successfully, yet it has additionally made critical difficulties for scholarly staff who feel progressively stressed to reexamine educating systems. This article looks to investigate the fundamental obstructions looked by scholastics in consolidating innovation into their instructing and proceeds to offer direction and reasonable tips for a progressively fruitful and learner centered approach educated by the writers' very own e-learning research, significant distributions and intelligent examination of their own training. Mindfulness is additionally raised in regards to review discoveries and exchanges with scholastics that affirm that fruitful execution of an e-learning technique over an organization depends fundamentally on senior administration's acknowledgment of the wide scope of instructive, administrative and mechanical help needs of showing staff and the remaining task at hand suggestions if new understudy needs are to be met viably. It is contended, besides, that foundations may be in the situation to draw on set up advantages of showing advances if staff improvement programs are updated to fuse rising advances and electronic assets and show how these might be mapped on to educational methodologies. To exhibit how the exercises learnt have been connected to date and depicts the continuous exercises in making the e-learning vision a reality at Napier University. Thusly, the work has a predominately UK center, instead of endeavoring to cover a wide scope of universal practice. First light G. Gregg (2007) the upsides of utilizing insightful specialists to encourage the area and customization of suitable e-learning assets and to cultivate joint effort in e-learning environments. E-learning operators ought to permit the revelation of new learning articles all the more effectively, enable students to tweak materials introduced to enhance learning results and enhance coordinated effort in the e-learning condition. 


\section{REVIEW OF LITERATURE}

The utilization of e-learning is to a great extent predicated upon the suspicion that it can encourage enhancements in understudy learning and in this way can be more viable than ordinary methods. This presumption has been bolstered by some in the writing yet has been addressed by a proceeding with assortment of opposite or apathetic proof. The motivation behind this paper is to enhance the hypothetical comprehension of the factors affecting e-learning viability, the way in which these factors have been concentrated to date, and to propose a reasonable applied model of e-learning adequacy to help its assessment. Attributable to an assortment of issues common in the writing, plainly the factors affecting viability are diverse and couple of analysts force sufficient controls or consider them explore structures George Macgregor and James Turner (2009), Georgios A. Dafoulas and Mike Mimirinis (2005) an at first surveys an e-learning framework contextual analysis (a center college and various related foundations named Global Campus) which consolidates: (I) the foundation of the Global Campus program looked into in light of concentrates on dispositions towards learning, examples of Virtual Learning Environment (VLE) use, computer assisted evaluation and learning assignments and examples of correspondence, and (ii) an e-learning situation dependent on the WebCT innovation for conveyance and appraisal. Aftereffects of four prior investigations with respect to (I) MBA training, (ii) examples of utilization of the VLE (iii) correspondence designs in e-learning and (iv) PC helped evaluation are likewise fundamentally assessed. Convincingly, a lot of rules for an innovation system are recommended and the creators' points of view for the characterization and the development of e-learning applications are given.

Gill Homan and Allan Macpherson (2005) while e-learning has potential, its prosperity is fundamentally restricted by setting which impacts the level of complexity and incorporation of e-learning and its capacity to add to the corporate college learning procedures and results. Further research is required on both the student encounter and in the more extensive assessment of learning results past straightforward factual assessment of cooperation. Key regions of trouble are recognized as: the attention on conventional e-learning arrangements; the obstruction forced by the base innovation dimension of the association; the abrogating worry for ROI to the detriment of student encounters; and the degree to which academic conceivable outcomes are not completely abused. Gordon Graham (2004) it endeavors to evaluate the insight of conceivable future blueprints as to innovation in e-learning and instruction.

Jane Bell (2007) the reason for this paper is to set out advancements in the realm of e-learning utilizing examples of new innovations being produced and utilized in the UK. E-learning is ending up more generally utilized and progressively flexible as innovation changes. It features the obstructions that can impede individuals drawing in with internet learning and demonstrates to stay away from these issues. It sets out the points of interest to organizations and students and gives instances of utilizations for various adapting needs. The advancement and utilization of haptic is investigated for instance of forefront practice. The paper gives a wakeup call to any experts who are not drawing in with the latest mechanical advancements. E-learning is setting down deep roots and is progressing quickly associations need to remain side by side of improvements on the off chance that they are to contend viably in the worldwide commercial center.

Kunal Sharma (2011) the different cost factors and in addition the advantages engaged with e-learning usage in customary instructive establishments, so that e-learning execution is a smooth procedure. Three methods of e-learning exist, in particular, significantly online mode; substitution mode; and supplemental mode, and the expenses of e-learning differ for each. The paper likewise portrays how to evaluate the achievement or disappointment of an e-learning venture. The sentimentalist plots the money related ramifications of e-learning and gives data on the different cost factors in actualizing an e-learning venture out of the blue. These variables ought to be properly recognized and given thought, if the benefits of e-learning are to be completely acknowledged and e-learning execution is to succeed. 
Lars Unneberg (2007) in the course of recent years, the quick e-learning market has developed to speak to a noteworthy segment of e-learning content. Fast e-learning is commonly used to portray e-learning programs that can be created rapidly and cheaply. Industry rules recommend that customary e-learning ventures created in-house can take 10-plus weeks from origination to conclusive distributing. Fast e-learning is intended to diminish this to half a month.

Paul Henry (2001) it considers e-learning center results of substance, innovation, and administrations. The accentuation is upon the significance of incorporated learning ways that change as indicated by the understudy, the subject material, the dimension of capability and corporate or understudy inclinations. Effective usage of e-learning requires indistinguishable administration responsibility from other mission critical organization-wide activities. Above all else e-learning should urge the gathering of people it targets, offering the student an asset that is viewed as engaging, profitable and gainful to their objectives and goals.

Sally Sambrook (2003) developments in data and correspondence advances could make new types of adapting, especially speaking to little associations, to beat conventional obstructions, for example, absence of budgetary assets, time, ability and offices. Little associations in provincial, fringe districts, for example, North Wales can profit by ICTs, not exclusively to help e-commerce, yet in addition to get to new open doors for learning and advancement, past the often-restricted neighborhood advertise. In any case, key discoveries from this exploration propose that there are critical boundaries to electronic picking up, including the absence of equipment and programming, and boss frames of mind. A model is introduced that recognizes measurements of, and factors impacting, e-learning from boss and representative points of view.

Sean Wolfgand Matsui Siqueira et al, (2007) a visual instrument to permit a superior investigation of the e-learning content is now being created. Notwithstanding, it is basic to create advanced putting away and recovering components that would make this methodology all the more intriguing. At the point when contrasted and different methodologies, for example, those dependent on semantic models and deductive models, the decline in intricacy makes acknowledgment and reception of this methodology by educators and instructional planners less demanding. Based on the reviews and research gap we have been formulated following objectives; measuring student satisfaction with e-learning environment in the web based private universities of India.

Research objective and questions as follows; pedestal on research objective of the study following research questions are used to achieve study objective:

1. How much satisfied are the students with the "information quality" mechanism in the courses studies in e-learning?

2. How much satisfied are the students with the "system quality" in the courses?

3. How much satisfied are the students with the "service quality"?

In this research manuscript greater marginally differs from previous review of literature. In particular, framework quality, data quality, and administration quality are the principle e-learning administration quality ascribed in the examinations, notwithstanding these investigations zeroed in on the achievement of the e-learning framework, not e-learning administration quality. Emphasized on center business (educating), facilitative or managerial administrations and uphold administrations, distinguished e-learning authoritative and uphold administration quality, e-learning teacher quality, e-learning precision, e-adapting course materials quality, and e-learning security and protection as the principle credits comprising in general e-learning administration quality, yet their examination is of exploratory nature with a restricted example size. Today, colleges are changing their system of overseeing associations with understudies by considering understudies as students and colleges as suppliers of instructive administration. From this point of view, the after effects of this examination are likewise predictable with that of past examinations on online help quality. 


\begin{tabular}{|c|l|}
\hline $\mathrm{H}_{0} 1$ & $\begin{array}{l}\text { E-learning system quality has a positive influence } \\
\text { on Perceived overall quality }\end{array}$ \\
\hline $\mathrm{H}_{0} 2$ & $\begin{array}{l}\text { E-learning information quality has a positive influ- } \\
\text { ence on Perceived overall quality }\end{array}$ \\
\hline $\mathrm{H}_{0} 3$ & $\begin{array}{l}\text { E-learning service quality has a positive influence } \\
\text { on Perceived overall quality }\end{array}$ \\
\hline $\mathrm{H}_{0} 4$ & $\begin{array}{l}\text { E-learning system quality has a positive influence } \\
\text { on user satisfaction }\end{array}$ \\
\hline $\mathrm{H}_{0} 5$ & $\begin{array}{l}\text { E-learning information quality has a positive influ- } \\
\text { ence on user satisfaction }\end{array}$ \\
\hline $\mathrm{H}_{0} 6$ & $\begin{array}{l}\text { E-learning service quality has a positive influence } \\
\text { on user satisfaction }\end{array}$ \\
\hline $\mathrm{H}_{0} 7$ & $\begin{array}{l}\text { Perceived overall quality has a positive influence on } \\
\text { user satisfaction }\end{array}$ \\
\hline $\mathrm{H}_{0} 8$ & $\begin{array}{l}\text { Perceived overall quality has a positive influence on } \\
\text { net outcome }\end{array}$ \\
\hline $\mathrm{H}_{0} 9$ & $\begin{array}{l}\text { User satisfaction has a positive influence on net } \\
\text { outcome }\end{array}$ \\
\hline & \\
\hline
\end{tabular}

\section{FORMULATION OF HYPOTHESIS}

\section{METHODOLOGY}

Both primary and secondary data were gathered for this examination. In social affair data relating to the examination; a poll was as utilized as primary data for information gathering in this investigation. A pre-trial of the poll was led to evaluate the element acceptability of the Likert scales. More distant more, the survey was pilot trying to increase extra help for substance validity and to get starting signs about develop validity and unwavering quality. Out of the 700 understudies got, 80 were fragmented or contained not interesting answers. 620 final year MBA students participated in Tamilnadu private colleges were regarded usable.

\section{RESULTS AND DISCUSSION}

The analyses of the demographics in $73.6 \%$ of respondents are male and $26.4 \%$ are female. The percentage of female is showing a decline.

Model fit values are follows; chi-squares 4.813, RMSEA 0.06, NFI 0.94, CFI 0.91, GFI 0.89, AGFI 0.90 and TLI 0.94. From Table 4, it has been noted that the results of this study fail to support Hypothesis 1 and 8 ("E-learning system service quality has a positive effect on perceived overall quality" and perceived overall quality and net outcome), the results do confirm the direct and indirect relationship among e-learning technology satisfaction, quality of e-learning service, and MBA education. Many realistic studies support the idea that e-learning technology is the best way to enhance organizational learning effectiveness. Institute, therefore, should provide high-quality 
International Journal of Web-Based Learning and Teaching Technologies

Volume 17 • Issue 2 • March-April 2022

Table 1.E-Learning

\begin{tabular}{|l|c|c|c|}
\hline \multirow{2}{*}{\multicolumn{1}{c|}{ E-Learning Quality parameters }} & \multicolumn{3}{c|}{ Descriptive Statistics } \\
\cline { 2 - 4 } & Mean & SD & 0.88 \\
\hline System Quality & 3.71 & 0.71 & 0.78 \\
\hline Information Quality & 3.45 & 0.65 & 0.91 \\
\hline Service Quality & 3.55 & 0.74 & Reliability Value \\
\hline
\end{tabular}

Figure 1. E-Learning Quality

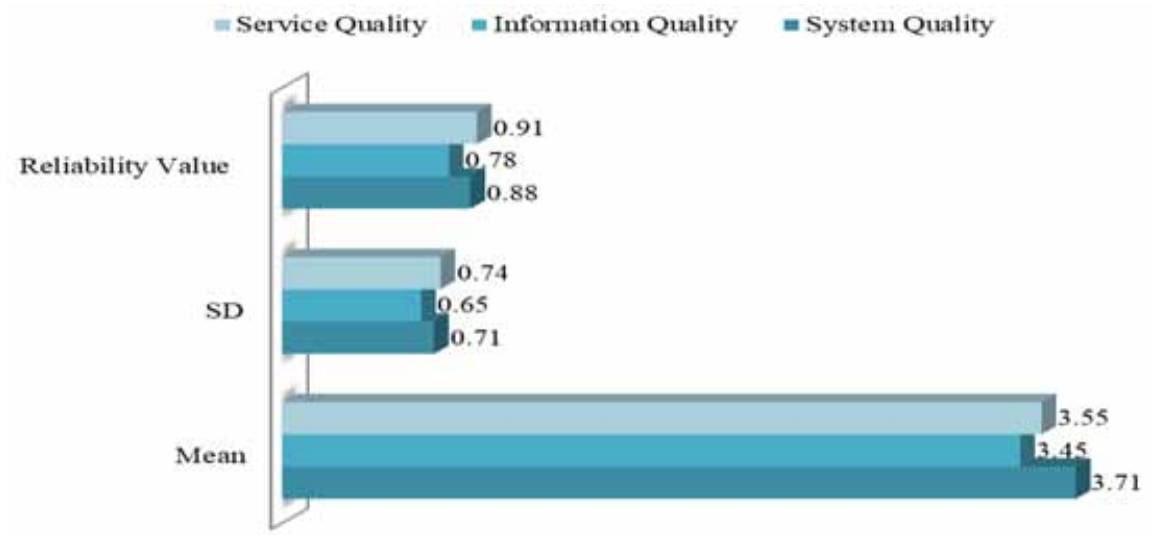


Figure 2. Maximum Likelihood Estimates and Regression Weights

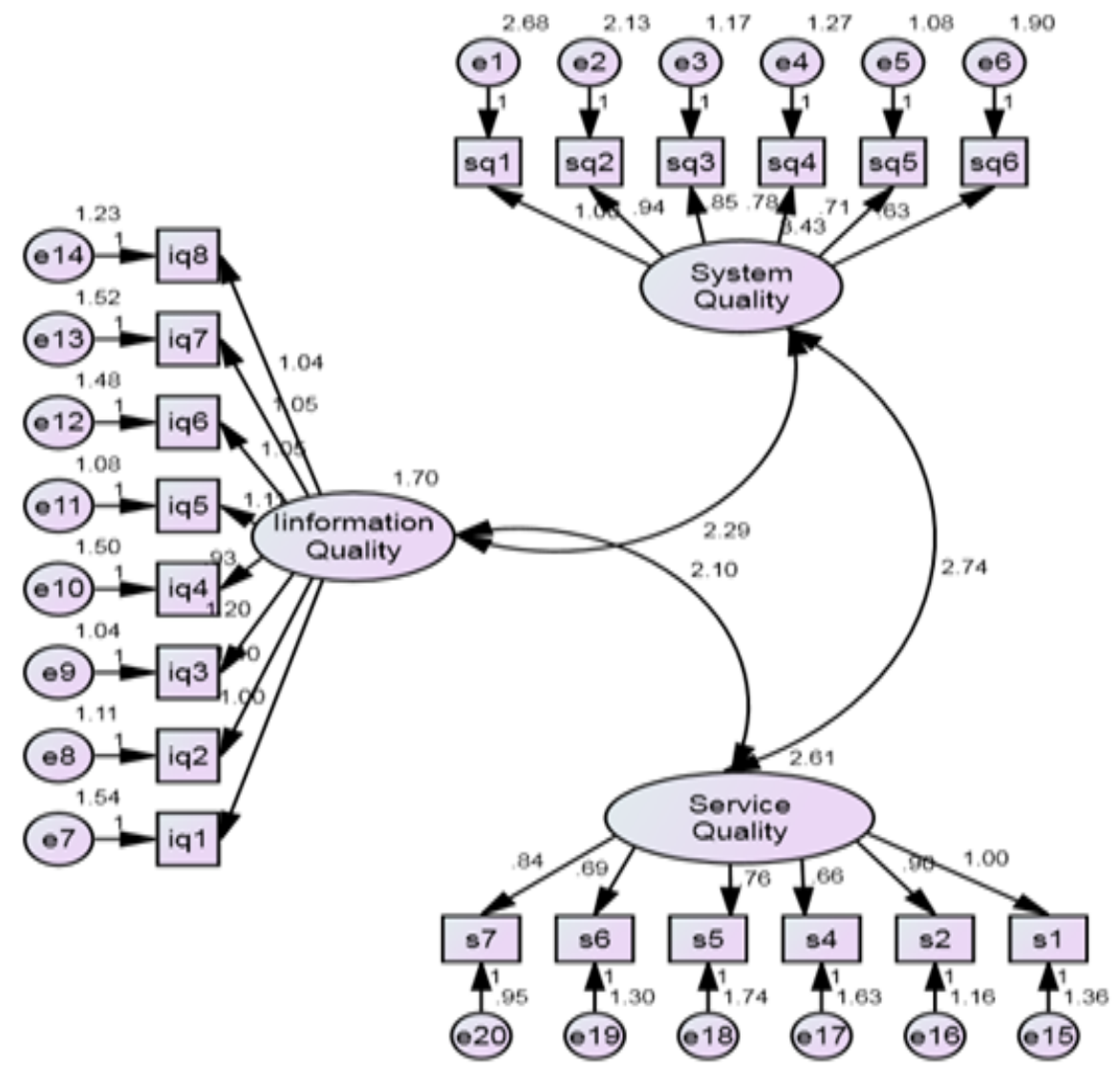


Table 2. Maximum Likelihood

\begin{tabular}{|c|c|c|c|c|c|}
\hline & & & S.E. & C.R. & $\mathbf{P}$ \\
\hline sq1 & $<---$ & \multirow{6}{*}{ Service Quality } & & & \\
\hline sq2 & $<---$ & & .068 & 13.852 & $* * *$ \\
\hline sq3 & $<---$ & & .056 & 14.978 & $* * *$ \\
\hline $\mathrm{sq} 4$ & $<---$ & & .055 & 14.247 & $* * *$ \\
\hline sq5 & $<---$ & & .050 & 14.171 & $* * *$ \\
\hline sq6 & $<---$ & & .055 & 11.414 & $* * *$ \\
\hline iq1 & $<---$ & \multirow{8}{*}{ Information Quality } & & & \\
\hline iq2 & $<---$ & & .090 & 15.489 & $* * *$ \\
\hline iq3 & $<---$ & & .080 & 14.935 & $* * *$ \\
\hline iq4 & $<---$ & & .075 & 12.455 & $* * *$ \\
\hline iq5 & $<---$ & & .077 & 14.452 & $* * *$ \\
\hline iq6 & $<---$ & & .079 & 13.263 & $* * *$ \\
\hline iq7 & $<---$ & & .080 & 13.159 & $* * *$ \\
\hline iq8 & $<---$ & & .076 & 13.761 & $* * *$ \\
\hline sy1 & $<---$ & \multirow{6}{*}{ System Quality } & & & \\
\hline Sy2 & $<---$ & & .050 & 13.632 & $* * *$ \\
\hline Sy3 & $<---$ & & .050 & 16.778 & $* * *$ \\
\hline Sy4 & $<---$ & & .058 & 13.185 & $* * *$ \\
\hline Sy5 & $<---$ & & .054 & 12.312 & $* * *$ \\
\hline Sy6 & $<---$ & & .054 & 16.509 & $* * *$ \\
\hline
\end{tabular}

Observed, endogenous variables

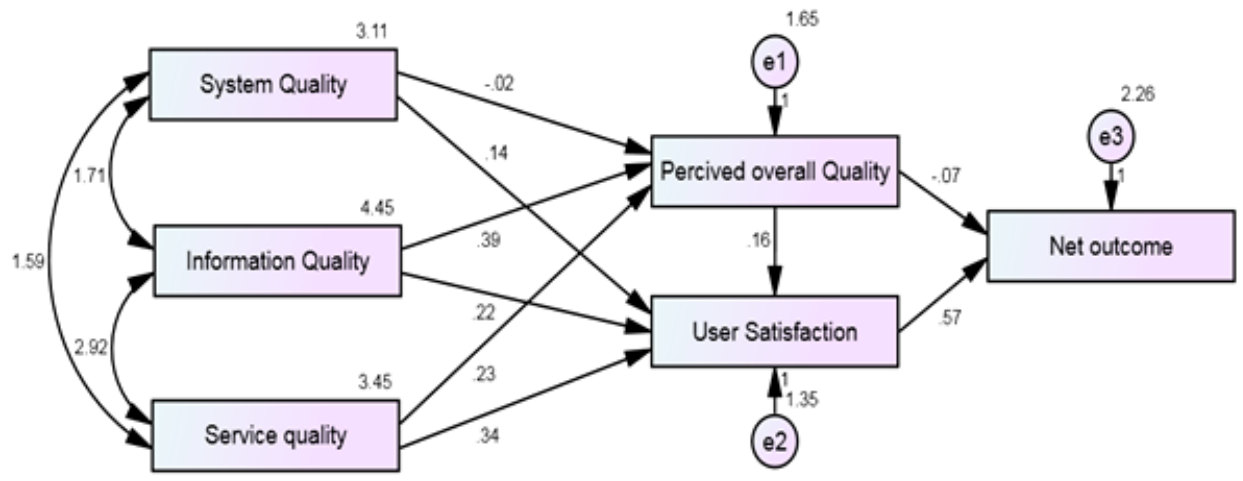


Table 3. Path Analysis

\begin{tabular}{|c|c|c|c|c|c|c|c|c|}
\hline & & & & Estimate & S.E. & C.R. & P & Sig. \\
\hline $\mathrm{H}_{0} 1$ & POQ & $<---$ & SYQ & -.020 & .034 & -.593 & 0.553 & Not supported \\
\hline $\mathrm{H}_{0} 2$ & POQ & $<---$ & IQ & .386 & .037 & 10.325 & $<0.001 * *$ & Supported \\
\hline $\mathrm{H}_{0} 3$ & POQ & $<---$ & SQ & .230 & .043 & 5.329 & $<0.001 * *$ & Supported \\
\hline $\mathrm{H}_{0} 4$ & US & $<---$ & SYQ & .137 & .031 & 4.445 & $<0.001 * *$ & Supported \\
\hline $\mathrm{H}_{0} 5$ & US & $<--$ & IQ & .219 & .037 & 5.964 & $<0.001 * *$ & Supported \\
\hline $\mathrm{H}_{0} 6$ & US & $<--$ & SQ & .336 & .040 & 8.417 & $<0.001 * *$ & Supported \\
\hline $\mathrm{H}_{0} 7$ & US & $<---$ & POQ & .156 & .037 & 4.261 & $<0.001 * *$ & Supported \\
\hline $\mathrm{H}_{0} 8$ & NOC & $<---$ & POQ & -.070 & .043 & -1.632 & 0.103 & Not supported \\
\hline $\mathrm{H}_{0} 9$ & NOC & $<---$ & US & .569 & .041 & 13.719 & $<0.001 * *$ & Supported \\
\hline
\end{tabular}

Table 4. Hypothesis results

\begin{tabular}{|c|c|c|}
\hline $\mathbf{H}_{0} \mathbf{1}$ & $\begin{array}{l}\text { E-learning system quality has a positive influence on Perceived } \\
\text { overall quality }\end{array}$ & Not supported \\
\hline $\mathrm{H}_{0} 2$ & $\begin{array}{l}\text { E-learning information quality has a positive influence on } \\
\text { Perceived overall quality }\end{array}$ & Supported \\
\hline $\mathrm{H}_{0} 3$ & $\begin{array}{l}\text { E-learning service quality has a positive influence on Perceived } \\
\text { overall quality }\end{array}$ & Supported \\
\hline $\mathrm{H}_{0} 4$ & $\begin{array}{l}\text { E-learning system quality has a positive influence on user } \\
\text { satisfaction }\end{array}$ & Supported \\
\hline $\mathrm{H}_{0} 5$ & $\begin{array}{l}\text { E-learning information quality has a positive influence on user } \\
\text { satisfaction }\end{array}$ & Supported \\
\hline $\mathrm{H}_{0} 6$ & $\begin{array}{l}\text { E-learning service quality has a positive influence on user } \\
\text { satisfaction }\end{array}$ & Supported \\
\hline $\mathrm{H}_{0} 7$ & $\begin{array}{l}\text { Perceived overall quality has a positive influence on user } \\
\text { satisfaction }\end{array}$ & Supported \\
\hline $\mathrm{H}_{0} 8$ & Perceived overall quality has a positive influence on net outcome & Not supported \\
\hline $\mathrm{H}_{0} 9$ & User satisfaction has a positive influence on net outcome & Supported \\
\hline
\end{tabular}

Observed, endogenous variablesObserved, endogenous variables 
e-learning service as the essential building block for better e-learning technology satisfaction in order to improve students learning effectiveness

\section{CONCLUSION}

This study investigated factors that lead to service quality of e-learning in MBA education environment which potentially trigger a new stream of research. The following is a brief discussion of the most important contributions this research offered for theory and practice. These contributions add to the benefit of the students, academic organizations and hopefully to society and other non-academic organizations. The research examined the components of e-learning service quality as information quality and system quality and further identified the dimensions of both. Based on the insights provided by the research studies conducted earlier on service quality and the antecedent information and system quality, this model has been conceptualized and constructed. The dimensions were used to design the construct and the instrument for measuring service quality of e-learning from the individual perspective. With the growth of MBA learning, institutions are seeking to improve this instructional mode and reduce the dropout rate caused by a number of factors, among which is students' dissatisfaction. Previous studies on e-learning indicate that student satisfaction with and use of the system generate net benefits of MBA learning in addition to playing a major role in student retention and maintenance, thus reducing the dropout rate. This study evaluated the antecedents of student satisfaction and use of systems in a virtual learning environment and showed the degree of importance of the dependent variables. The results indicate that Information Quality had a greater impact on Satisfaction and Use, followed by Service Quality and System Quality. One can state that students' degree of satisfaction and use of a system will be greater when they perceive higher information quality, whereas System Quality and net outcome had the scrawniest power of interconnection within the model. When making investment decisions, managers having this awareness can evaluate the dimensions that warrant attention, thus generating intelligent solutions that create a quality MBA-learning structure. In an effort to find links to other dimensions of the Satisfaction and System Use constructs, future studies may propose new approaches to the model to examine issues such as the dropout rate, net benefits, and students' intention to continue with a MBA-learning program. A limitation of this study is the possible impact of using a 5-point Likert scale. Nevertheless, the model's adjustment indices were not greatly affected. In addition, good results can be obtained when one uses Likert-type scales with at least five categories. 


\section{REFERENCES}

Bell, J. (2007). E-learning: Your flexible development friend? Development and Learning in Organizations, 21(6), 7-9. doi:10.1108/14777280710828558

Bennet, A., \& Bennet, D. (2008). e-Learning as energetic learning. Vine, 38(2), 206-220. doi:10.1108/03055720810889842

Dafoulas, G. A., \& Mimirinis, M. (2005). Communication patterns in e-learning communities. Interactive Technology and Smart Education, 2(4), 221-233. doi:10.1108/17415650580000046

Graham, G. (2004). E-learning: A philosophical enquiry. Education + Training, 46(6/7), 308-314. doi:10.1108/00400910410555213

Gregg,D. G. (2007).E-learning agents. The Learning Organization, 14(4),300-312.doi:10.1108/09696470710749245

Henry, P. (2001). E-learning technology, content and services. Education + Training, 43(4/5), 249-255. doi:10.1108/EUM0000000005485

Homan, G., \& Macpherson, A. (2005). E-learning in the corporate university. Journal of European Industrial Training, 29(1), 75-90. doi:10.1108/03090590510576226

Little. (2001). Achieving high performance through e-learning. Industrial and Commercial Training, 33(6), 203-207.

Macgregor, G., \& Turner, J. (2009). Revisiting e-learning effectiveness: Proposing a conceptual model. Interactive Technology and Smart Education, 6(3), 156-172. doi:10.1108/17415650911005375

Mainka, C., \& Benzies, A. (2006). E-learning: Vision to reality. Interactive Technology and Smart Education, 3(2), 101-111. doi:10.1108/17415650680000056

Rhee, C., Moon, J., \& Choe, Y. (2006). Web interface consistency in e-learning. Online Information Review, 30(1), 53-69. doi:10.1108/14684520610650309

Sambrook, S. (2003). E-learning in small organizations. Education + Training, 45(8/9), 506-516. doi:10.1108/00400910310508892

Sean, W. M. S. (2007). Modeling e-learning content. International Journal of Web Information Systems, 3(1/2), 140-152. doi:10.1108/17440080710829261

Sharma, K. (2011). Financial implications of implementing an e-learning project. Journal of European Industrial Training, 35(7), 658-686. doi:10.1108/03090591111160788

Unneberg, L. (2007). Rapid e-learning at enterprise level. Strategic HR Review, 6(3), 4-4. doi: $10.1108 / 14754390780000958$ 